\title{
Flora do Espírito Santo: Subtribo Terminaliinae (Combretaceae)
}

\author{
Flora of Espírito Santo: Terminaliinae subtribe (Combretaceae)
}

\author{
Rayane de Tasso Moreira Ribeiro ${ }^{1,3}$, Maria Iracema Bezerra Loiola ${ }^{2}$ \& Margareth Ferreira de Sales ${ }^{1}$
}

\begin{abstract}
Resumo
Este estudo teve como objetivo realizar o levantamento florístico da subtribo Terminaliinae no estado do Espírito Santo. Baseou-se na análise comparativa dos caracteres morfológicos de espécimes depositados nos herbários BHCB, BM, CEPEC, CESJ, CRVD, EAC, ESA, HUFU, LTR, MBML, NY, RB, SP, UB e VIES, bibliografias especializadas e imagens de coleções-tipo. No Espírito Santo foram registradas nove espécies distribuídas em três gêneros: Buchenavia (B. hoehneana, B. kleinii, B. parvifolia e B. tetraphylla), Conocarpus (C. erectus) e Terminalia (T. argentea, T. glabrescens, T. januariensis e T. mameluco). As espécies de Terminaliinae ocorrem preferencialmente em floresta ombrófila densa (mata úmida) e foram registradas em apenas três unidades de conservação do estado: APA Pedra do Elefante, Parque Natural Municipal de São Lourenço e Reserva da Companhia Vale do Rio Doce.

Palavras-chave: conservação, diversidade, Myrtales, Sudeste do Brasil.
\end{abstract}

\begin{abstract}
This study aimed to conduct a floristic survey of the subtribe Terminaliinae in the state of Espírito Santo. It was based on the morphological analysis of specimens deposited in herbaria BHCB, BM, CEPEC, CESJ, CRVD, EAC, ESA, HUFU, LTR, MBML, NY, RB, SP, UB and VIES, specialized bibliographies and images of type-collections. In the state of Espírito Santo, nine species were recorded in three genera: Buchenavia (B. hoehneana, B. kleinii, B. parvifolia, B. tetraphylla), Conocarpus (C. erectus) and Terminalia (T. argentea, T. glabrescens, T. januariensis and T. mameluco). Terminaliinae species occur preferentially in ombrophyllous dense forest and were recorded only in three conservation units of the state: APA Pedra do Elefante, Municipal Natural Park of São Lourenço and Vale do Rio Doce Natural Reserve.
\end{abstract}

Key words: conservation, diversity, Myrtales, Southeastern Brazil.

\section{Introdução}

Combretaceae abrange 14 gêneros e aproximadamente 500 espécies, distribuídas nos trópicos e subtrópicos (Maurin et al. 2010; Stace 2010). Caracteriza-se pelo hábito arbóreo; tricomas lepidotos distintos nas porções vegetativas e reprodutivas; folhas simples, inteiras; flores tetrâmeras ou pentâmeras; ovário ínfero, exceto em Strephonema Hook f. e frutos indeiscentes, unispermados (Stace 2010; Soares Neto et al. 2014).

Engler \& Diels (1900) subdividiram Combretaceae em duas subfamílias: Strephonematoideae Engl. \& Diels, restrita ao continente africano, e Combretoideae Burnett, incluindo as tribos Laguncularieae Engl. \& Diels e Combreteae DC., com 490 representantes. Em Combreteae foram reconhecidas as subtribos Pteleopsidinae, Combretinae, onde está inserido Combretum Loefl., e Terminaliinae (DC.) Exell \& Stace que inclui os gêneros Buchenavia Eichler, Conocarpus L. e Terminalia L. (Exell \& Stace 1966). A circunscrição das subtribos foi proposta com base em diferenças nos tricomas e estrutura da inflorescência.

As características morfológicas que distinguem Terminaliinae dos demais grupos de Combretaceae incluem folhas alterno-espiraladas, inflorescências em espigas ou panículas de espigas

\footnotetext{
${ }^{1}$ Universidade Federal Rural de Pernambuco, Depto. Biologia, Prog. Pós-graduação em Botânica, Dois Irmãos, 52171-900, Recife, PE, Brasil.

${ }^{2}$ Universidade Federal do Ceará, Depto. Biologia, Lab. Sistemática e Ecologia Vegetal (LASEV), bl. 906, Campus do Pici Prof. Prisco Bezerra, 60440-900, Fortaleza, CE, Brasil.

${ }^{3}$ Autora para correspondência: rayanetasso@gmail.com
} 
(terminais ou axilares) e ausência de corola (Alwan 1983; Gere 2013; Soares Neto et al. 2014). Dentre os gêneros que constituem a subtribo Terminaliinae, Terminalia apresenta o maior número de espécies (cerca de 200) com distribuição pantropical e constitui, quase exclusivamente, as Combretaceae tropicais (Stace 1965; 2010). No Brasil, Terminaliinae está representada por 41 espécies, destas 18 ocorrem na Região Sudeste (BFG 2015).

Os representantes de Terminaliinae destacamse pela qualidade da madeira, em especial em Buchenavia e Terminalia (Stace 2010). Além disso, são reportadas na literatura propriedades farmacológicas para B. tetraphylla (Aubl.) R.A. Howard, cujo extrato das folhas apresenta bioatividade contra cepas de Candida albicans (Cavalcanti Filho et al. 2017)

Na medicina popular, Terminalia acuminata (Allemão) Eichler é, comumente, utilizada no tratamento da febre amarela e hepatite (Cock 2015). Enquanto, T. actinophylla Mart. apresenta propriedades anti-inflamatórias, sedativas e antidiarreica, respectivamente (Ribeiro et al. 2012; Pádua et al. 2013).

A diversidade taxonômica das espécies de Combretaceae do Brasil, especificamente da subtribo Terminaliinae, foi inicialmente tratada na Flora brasiliensis por Eichler (1867). Posteriormente, os representantes de Terminaliinae foram alvo de alguns tratamentos taxonômicos ou listagens de espécies em floras regionais ou estaduais, destacando-se os estudos de Loiola et al. (2009), Soares Neto et al. (2014) e Sousa et al. (no prelo) que listaram as Combretaceae da Região Nordeste, especificamente dos estados da Paraíba, Ceará e Rio Grande do Norte, respectivamente. Linsigen et al. (2009) registraram as Combretaceae da Região Sul. Enquanto Marquete (1984), Marquete \& Valente (1997) e Marquete et al. (2003) levantaram as espécies ocorrentes na Região Sudeste.

Diante do exposto, este trabalho visando contribuir para o conhecimento da flora estadual, teve como objetivo inventariar os representantes da subtribo Terminaliinae no estado do Espírito Santo, provendo descrições, chaves de identificação, pranchas fotográficas e dados atualizados sobre a distribuição geográfica das espécies.

\section{Material e Métodos}

Este estudo fundamentou-se na análise comparada de espécimes depositados nos herbários BHCB, BM, CEPEC, CESJ, CRVD, EAC,
ESA, HUFU, LTR, MBML, NY, RB, SP, UB e VIES, cujas siglas estão de acordo com Thiers (contiuamente atualizado).

As determinações foram realizadas com o auxílio de literatura especializada (ex. Marquete 1984; Marquete et al. 2003; Stace 2010; Soares Neto et al. 2014) e análise dos espécimes de coleções-tipo ou imagens, disponíveis nos herbários BM, BR, G, K, LE, M, MO, OXF, P, PRC, RB, SP, SPSF, TCD, W e WIS. Os nomes dos autores estão de acordo com IPNI (2017).

Os caracteres morfológicos foram descritos baseado nos trabalhos de Radford et al. (1974) e Hickey (1973) para designar o padrão de nervação. Materiais adicionais de outros estados foram utilizados para complementar as descrições de espécies com ausência de flores e/ou frutos. Dados referentes à forma de crescimento (hábito), hábitat, período de floração e frutificação e nomes populares foram obtidos das etiquetas das exsicatas. A descrição de cada gênero seguiu um padrão próprio para descrição das características morfológicas.

A distribuição das espécies foi verificada através de mapas gerados no programa Quantum GIS 2.16.8 (QGIS 2017). No caso de ausência das coordenadas geográficas associadas à localidade das coletas nas etiquetas das exsicatas, utilizou-se as coordenadas do município obtidas a partir da ferramenta geoLoc (CRIA 2017).

\section{Resultados e Discussão}

A subtribo Terminaliinae está representada no estado do Espírito Santo por nove espécies (três endêmicas do Brasil) distribuídas em três gêneros: Buchenavia Eichler (B. hoehneana N.F. Mattos, B. kleinii Exell, B. parvifolia Ducke, B. tetraphylla (Aubl.) R.A. Howard), Conocarpus L. (C. erectus L.) e Terminalia L. (T. argentea Mart., T. glabrescens Mart., T. januariensis DC. e T. mameluco Pickel. Neste estudo, o espécime de Terminalia fagifolia Mart., G.M. Barroso 16 (RB), referido para o estado do Espírito Santo, em localidade provavelmente do estado do Piauí, não foi considerado. Registrou-se, ainda, a ocorrência de uma espécie naturalizada, T. catappa L., que também não foi tratada.

Terminalia riedelii Eichler foi citada para o estado do Espírito Santo por Marquete et al. (2003) e BFG (2015), sendo considerada uma espécie pouco conhecida e representada apenas pelos espécimes-tipo e a coleção Souza 247 (CRVD). Segundo Marquete et al. (2003), a coleção Souza 247 (CRVD) apresentava características similares 
as da descrição original de $T$. riedelii, tais como: folhas pequenas (ca. 4,5 × $2 \mathrm{~cm}$ ), inflorescências com pedúnculo curtíssimo (3-5 $\mathrm{mm}$ compr.) e aglomeradas em fascículos opostos às folhas. No entanto, após a análise do material-tipo coletado por Riedel 1162 (NY) no estado do Rio de Janeiro, não foi possível chegar a uma conclusão e optou-se por também não considerar essa espécie.

No Espírito Santo, os representantes da subtribo Terminaliinae habitam preferencialmente ambientes de climas mais úmidos, como floresta ombrófila densa (mata úmida) (Garbin et al. (2017)). A exceção foi $C$. erectus registrada em ambientes de mangue.

As espécies de Terminaliinae apresentaram registros apenas em três unidades de conservação do estado: Área de Proteção Ambiental (APA) da Pedra do Elefante, Parque Natural Municipal de São Lourenço e Reserva Natural da Vale do Rio Doce. Esses resultados evidenciam a necessidade de um maior esforço de coleta para que novos registros sejam adicionados para o estado, o qual se encontra, muito provavelmente, subamostrado. Ou ainda, que os representantes da subtribo podem estar correndo risco de extinção, devido a atividades antrópicas na área, como por exemplo, o desmatamento.

\section{Tratamento taxonômico}

Combretaceae R. Br., Prodr. Fl. Nov. Holl.: 351. 1810.

Arbustos ou árvores, monoicos. Folhas alternas, simples, inteiras; glândulas 2 ou ausentes, no ápice do pecíolo; domácias presentes ou ausentes. Inflorescências em espigas, racemos de espigas, ou ainda capítulos globosos, terminais ou axilares. Bractéolas presentes. Flores actinomorfas, monóclinas, pentâmeras, hipanto dividido em duas porções: uma inferior (que envolve o ovário) e superior (em tubo curto ou alongado); cálice 5 lobado, geralmente pouco desenvolvido; pétalas ausentes; androceu diplostêmone, estames 10, em dois verticilos, exsertos, filiformes; anteras versáteis ou adnatas aos filetes, rimosas; disco nectarífero desenvolvido ou inconspícuo na base da parede do hipanto superior, margem vilosa; ovário ínfero, unilocular, 2-3 rudimentos seminais pêndulos. Frutos indeiscentes, betulídeos ou drupáceos, 2-5-alado ou não, menos frequente alas inconspícuas ou vestigiais.

\section{Chave de identificação dos gêneros de Terminaliinae ocorrentes no Espírito Santo}

1. Arbustos a árvores de manguezal; pecíolo com duas glândulas secretoras de sal; flores e frutos agrupados em capítulos globosos 2. Conocarpus

1'. Arbustos a árvores de outros ambientes; pecíolo sem glândulas secretoras de sal; flores e frutos arranjados em espigas ou racemos de espigas.

2. Lobos do cálice inconspícuos $(<2,5 \mathrm{~mm}$ compr.), fruto drupáceo ......................... 1. Buchenavia

2'. Lobos do cálice desenvolvidos ( $>5 \mathrm{~mm}$ compr.); fruto betulídeo, 2-5 alado ......... 3. Terminalia

1. Buchenavia Eichler, Flora 49: 164. 1866.

Arbustos a árvores. Folhas aglomeradas no ápice dos ramos, geralmente obovadas ou oblanceoladas, ápice arredondado a retuso, às vezes mucronado, base atenuada; glândulas 2 , ou ausentes, quando presentes nunca secretoras de sal. Domácias, em geral, ausentes. Inflorescências em espigas axilares, alongadas, subcapitadas a capitadas. Flores diminutas, hermafroditas e masculinas encontradas na mesma inflorescência. Hipanto inferior envolvendo o ovário e prolongado acima deste; hipanto superior cupuliforme, lobos do cálice 5, inconspícuos. Pétalas ausentes. Estames com filetes espessos e curtos; anteras adnatas aos filetes. Disco nectarífero viloso. Estilete curto; estigma agudo ou truncado; ovário com 2-3 rudimentos seminais. Fruto arranjados em espigas, geralmente elíptico, oval-elíptico, oblongo ou subobovado.

Buchenavia é um gênero endêmico da América com cerca de 20 espécies, das quais 18 são restritas à América do Sul. Tem por centro de diversidade a bacia do rio Amazonas (Stace 2010). No Brasil, foram registradas 17 espécies de ampla distribuição, com maior diversidade (15 spp.) no estado do Amazonas (Marquete 2012; BFG 2015). Buchenavia está representada na Região Sudeste por cinco espécies (BFG 2015), destas quatro ocorrem no estado do Espírito Santo e são aqui descritas. 


\section{Chave de identificação das espécies de Buchenavia ocorrentes no Espírito Santo}

1. Folhas com 9-15 × 3,5-5,6 cm; 9-14 pares de nervuras secundárias; pecíolo com 2 glândulas nunca secretoras de sal 1.1. Buchenavia hoehneana

1'. Folhas 2,2-6,8 × 0,8-3,9 cm; 4-8 pares de nervuras secundárias; pecíolo sem glândulas.

2. Folhas cartáceas, glabras 1.3. Buchenavia parvifolia

2'. Folhas subcoriáceas a coriáceas, subglabras a tomentosas ou seríceas.

3. Bracteóla ovada; fruto elíptico ou subobovado 1.2. Buchenavia kleinii

3'. Bracteóla cimbiforme; fruto oval-elíptico 1.4. Buchenavia tetraphylla

1.1. Buchenavia hoehneana N.F. Mattos, Loefgrenia 21: 1. $1967 . \quad$ Figs. 1; 2a,b = Buchenavia pabstii Marquete \& C. Valente, Atas Soc. Bot. Brasil, Secç. Rio de Janeiro 3(14): 113. 1992.

Árvores ca. $27 \mathrm{~m}$ alt. Folhas 9-15 $\times$ $3,5-5,6 \mathrm{~cm}$, coriáceas, subglabras a rufo-seríceas na face abaxial e subglabras na face adaxial; nervura principal tomentosa; lâmina obovada a oblanceolada, ápice arredondado ou mucronado, base atenuada; nervação broquidódroma, 9-14 pares de nervuras secundárias; pecíolo 1,5-2,2 cm compr.; domácias marsupiformes, revestidas por tricomas nas axilas da nervura principal com as secundárias; glândulas 2, diminutas. Inflorescência ca. $11 \mathrm{~cm}$ compr., espigas, axilares, alongadas, pedúnculo ca. $4,2 \mathrm{~cm}$ compr., raque ca. $6,6 \mathrm{~cm}$ compr. Bractéola 4-4,5 × 1-1,5 mm, linearlanceolada, vilosa; botão floral não observado. Flores 7-9 mm compr.; hipanto inferior 4-5 $\mathrm{mm}$ compr., rufo-viloso; hipanto superior 2-2,5 mm compr., glabro a piloso; lobos do cálice 2-2,5 ×

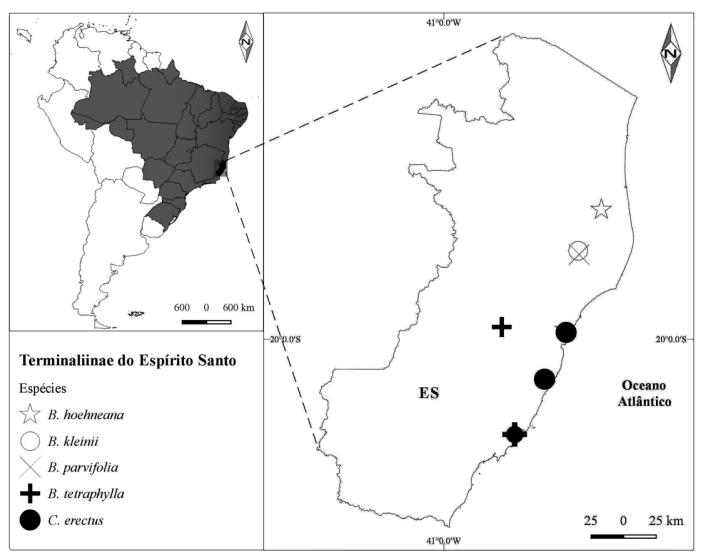

Figura 1 - Distribuição de Buchenavia e Conocarpus no estado do Espírito Santo, Sudeste do Brasil.

Figure 1 - Distribution of Buchenavia and Conocarpus in Espírito Santo state, Southeastern Brazil.
3-4,8 mm, pilosos; estames com filetes do verticilo externo $1,2-1,3 \mathrm{~mm}$ compr., filetes do verticilo interno $0,8-1 \mathrm{~mm}$ compr.; anteras $0,8-0,9 \times$ $0,5-0,6 \mathrm{~mm}$, elípticas; disco nectarífero aneliforme. Ovário $0,8-1 \mathrm{~mm}$ compr.; estilete $3,2-3,3 \mathrm{~mm}$ compr.; estigma agudo. Fruto ca. 2,0 $\times 1 \mathrm{~cm}$, oblongo, ápice agudo, base curto-estipitada.

Material selecionado examinado: Linhares, Reserva Florestal da CVRD, 15.XII.1980, fl., I.A. Silva 226 (BM, CRVD, RB).

Buchenavia hoehneana é facilmente distinguível, das demais espécies do gênero aqui descritas, por apresentar folhas maiores $(9-15 \times$ $3,5-5,6 \mathrm{~cm}$ ), coriáceas, nervação broquidódroma com 9-14 pares de nervuras secundárias, domácias marsupiformes, revestidas por tricomas nas axilas da nervura principal com as secundárias; glândulas 2, diminutas, inflorescências $(11 \mathrm{~cm}$ compr.) e flores maiores (7-9 $\mathrm{mm}$ compr.), estames 10, estigma agudo e frutos oblongos. Buchenavia pabstii Marquete \& C. Valente, sinonimizada $\operatorname{sob} B$. hoehneana, foi descrita para o Espírito Santo como nova devido o indumento rufo-seríceo na face abaxial das folhas, pecíolo com duas glândulas diminutas, 9-14 pares de nervuras secundárias, flores maiores e frutos curto-estipitados (Marquete \& Valente 1992). Segundo Stace (2010), B.hoehneana e B. pabstii não podem ser consideradas espécies distintas, proposta aceita no presente estudo. Buchenavia hoehneana é endêmica do Brasil com ocorrência nos estados da Bahia, São Paulo, Rio de Janeiro, Minas Gerais e Espírito Santo (BFG 2015), em Floresta Ombrófila Densa. A espécie é amplamente distribuída em território brasileiro, porém está representada no estado do Espírito Santo por registros em apenas uma área, sendo considerada vulnerável (VU) (IUCN 2010), ou ainda "quase ameaçada (NT)" (CNCFlora 2017). Registrada com flores em dezembro e frutos em agosto. Conhecida popularmente como "pequi izaias". 


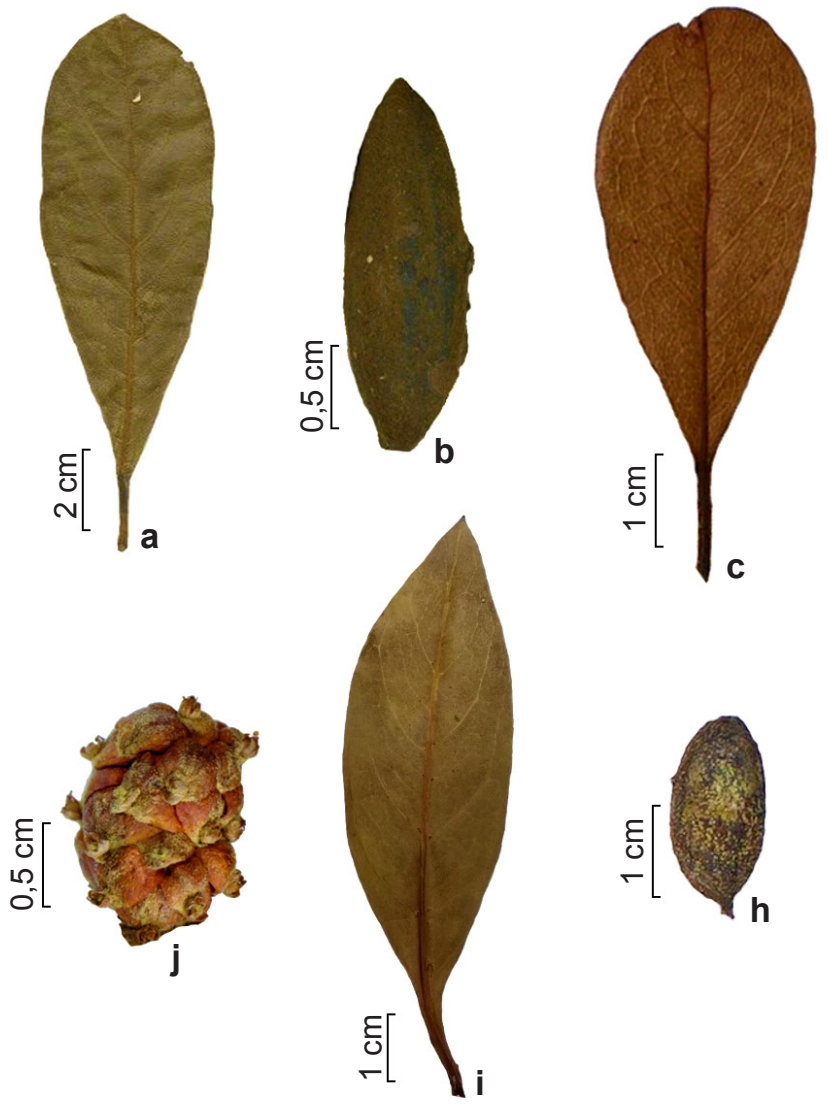

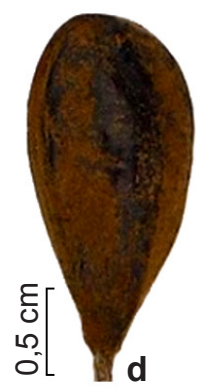
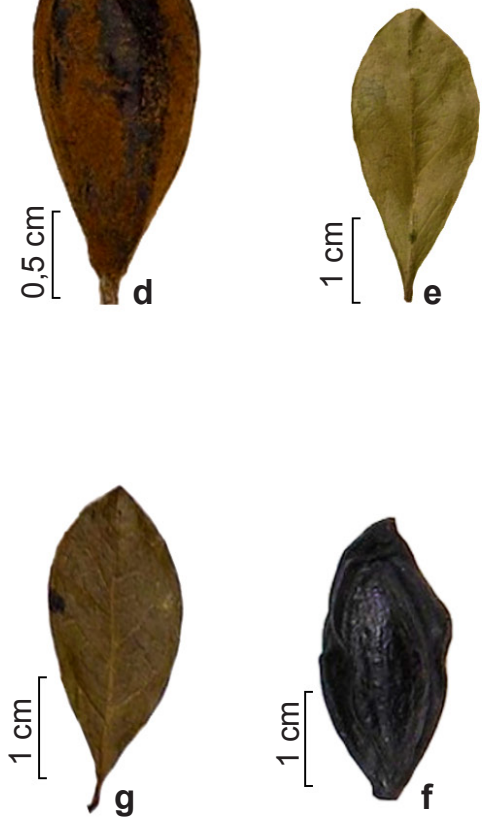

Figura 2 - a-b. Buchenavia hoehneana - a. folha, b. fruto. c-d. B. kleinii - c. folha, d. fruto. e-f. B. parvifolia - e. folha, f. fruto. g-h. B. tetraphylla - g. folha, h. fruto. i-j. Conocarpus erectus - i. folha, j. inflorescência. (a. I.A. Silva 226, RB 537351; b. D.A. Folli 384, RB 296897; c,d. J.G. Kuhlmann s.n., RB 25743; e,f. D.A. Folli 544, RB 322478; g,h. V. Demuner 351, RB 390993; i,j. T.M.S. Carmo s.n., VIES 285).

Figure 2 - a-b. Buchenavia hoehneana - a. leaf, b. fruit. c-d. B. kleinii - c. leaf, d. fruit. e-f. B. parvifolia - e. leaf, f. fruit. g-h. B. tetraphylla - g. leaf, h. fruit. i-j. Conocarpus erectus - i. leaf, j. inflorescence. (a. I.A. Silva 226, RB 537351; b. D.A. Folli 384, RB 296897; c,d. J.G. Kuhlmann s.n., RB 25743; e,f. D.A. Folli 544, RB 322478; g,h. V. Demuner 351, RB 390993; i,j. T.M.S. Carmo s.n., VIES 285).

1.2. Buchenavia kleinii Exell, Ann. Mag. Nat. Hist., ser. 12 6: 400. 1953.

Figs. 1; 2c,d $=$ Buchenavia igaratensis N.F. Mattos, Loefgrenia 24: 1.1967.

Árvores $15-20 \mathrm{~m}$ de alt., glabra. Folhas $5-6,2 \times 2,7-2,8 \mathrm{~cm}$, subcoriáceas, subglabras a tomentosas, em especial na nervura principal; lâmina obovada, ápice arredondado a retuso, base atenuada; nervação broquidódroma, $4-8$ pares de nervuras secundárias; pecíolo $0,7-1 \mathrm{~cm}$ compr.; domácias e glândulas ausentes. Inflorescência 1,5-2,5 cm compr., espigas, axilares, subcapitadas; pedúnculo ca. $2 \mathrm{~cm}$ compr., raque ca. $0,9 \mathrm{~cm}$ compr. Brácteola 1,5-2,5 × 1-1,5 cm, ovada, glabra a velutino-rufescente; botão floral não observado.
Flores 4,2-4,5 mm compr.; hipanto inferior 1,5-3 mm compr., rufo-viloso; hipanto superior ca. 1,5 $\mathrm{mm}$ compr., glabro; lobos do cálice inconspícuos; estames com filetes do verticilo externo $0,8-1 \mathrm{~mm}$ compr., filetes do verticilo interno $1,2-1,3 \mathrm{~mm}$ compr.; anteras $0,4-0,5 \times 0,4-0,5 \mathrm{~mm}$, orbiculares; disco nectarífero aneliforme. Ovário ca. 0,7 mm compr.; estilete $1,8-2 \mathrm{~mm}$ compr.; estigma truncado. Fruto 2,8-3 × 1,5-2,1 mm, elíptico ou subobovado, ápice arredondado, base aguda.

Material selecionado examinado: Linhares, Reserva Florestal da Vale, 15.VII.1970, fl., T.S. dos Santos 951 (CEPEC, LTR, MBML).

Material adicional: BRASIL: RIO DE JANEIRO: Horto Florestal, 24.I.1928, fr., J.G. Kuhlmann (RB 25743). 
Buchenavia kleinii é morfologicamente muito relacionada à $B$. tetraphylla, o que dificultou a delimitação dos dois táxons. No material analisado, a distinção de B. kleinii foi possível devido suas folhas subcoriáceas (vs. coriáceas), bracteóla ovada ( $v s$. cimbiforme) e fruto elíptico ou subobovado (vs. oval-elíptico). Segundo Stace (2010), um considerável número de espécimes com flores e frutos, em especial do estado do Espírito Santo, deve ser analisado para melhor delimitação destas espécies. Com este estudo, tornou-se ainda mais evidente a necessidade de um maior esforço de coleta com o intuito de contribuir na definição dos táxons de Buchenavia do Sudeste do Brasil. Buchenavia kleinii é uma espécie restrita ao território brasileiro, apresentando distribuição relativamente ampla nos estados do Sudeste e Sul habitando diversas formações florestais na Mata Atlântica (CNCFlora 2017). No Espírito Santo foi registrada apenas na Reserva Florestal da Vale em Floresta Ombrófila Densa. Segundo IUCN (2010), a espécie foi considerada "menos preocupante/quase ameaçada" (LC/NT). Registrada com flores em julho. Popularmente conhecida como "pequi gigante".

1.3. Buchenavia parvifolia Ducke Arch. Jard. Bot. Rio de Janeiro 4: 150. 1925.

1.3.1. Buchenavia parvifolia subsp. rabelloana (Mattos) Alwan et Stace Fl. Neotrop. Monogr. 107: 275. 2010. Figs. 1; 2e, $\mathrm{f}$

= Buchenavia rabelloana Mattos Ci. \& Cult. 19: 333. 1967.

Árvores ca. $31 \mathrm{~m}$ de alt., glabras. Folhas 2,2-3,4 × 0,8-1,4 cm, cartáceas, glabras; lâmina obovada, ápice arredondado, base atenuada; nervação broquidódroma, 4-6 pares de nervuras secundárias; pecíolo 0,5-0,7 cm compr.; domácias e glândulas ausentes. Inflorescência, bractéola e flores não observadas. Fruto $2-2,4 \times 1-1,2 \mathrm{~cm}$, elíptico a obovado, ápice curto-apiculado, base curto-estipitada.

Material selecionado examinado: Linhares, Reserva Florestal da Vale, Estrada Farinha Seca, 29.III.2003, fr., D.A. Folli 544 (CRVD, RB).

Buchenavia parvifolia distingue-se das demais espécies analisadas por possuir folhas menores $(2,2-3,4 \times 0,8-1,4 \mathrm{~cm})$ e cartáceas. B. parvifolia é segregada em duas subespécies: Buchenavia parvifolia Ducke subsp. parvifolia restrita à Região Norte do Brasil (domínio amazônico), enquanto B. parvifolia subsp. rabelloana ocorre no Sudeste do Brasil e caracteriza-se pelo ovário denso-pubescente (vs. glabro) (Stace 2010). Em território brasileiro, B. parvifolia apresenta registro nas regiões Norte e Sudeste, em Floresta Ombrófila Densa (BFG 2015). No Espírito Santo foi encontrada apenas na Reserva Florestal da Vale, também em Floresta Ombrófila Densa. Registrada com frutos em março. Popularmente conhecida como "pequi mirindiba".

1.4. Buchenavia tetraphylla (Aubl.) R.A. Howard, J. Arnold Arbor. 64(2): 266. 1983. Figs. 1; 2g-h = Buchenavia capitata Vahl, Eclog. Amer. 1: 50, t. 8, f. 1. 1796.

Arbustos a árvores 4-30 m alt., glabras. Folhas 2,2-6,8 × 1,3-3,9 cm, coriáceas, subglabras a seríceas, em ambas as faces; lâmina obovada, ápice arredondado ou retuso, base atenuada; nervação broquidódroma, 5-7 pares de nervuras secundárias; pecíolo $0,3-3 \mathrm{~cm}$ compr.; domácias e glândulas ausentes. Inflorescências ca. 2,2 cm compr., espigas, axilares, capitadas, pedúnculo $1-1,2 \mathrm{~cm}$ compr., raque ca. $1,5 \mathrm{~cm}$ compr. Bractéola ca. 1,5 mm compr., cimbiforme, vilosa; botão floral 1-1,5 × 0,9-1,5 mm, capitado. Flores $3-4,5 \times 3-3,5 \mathrm{~mm}$, esverdeadas; hipanto inferior $1,5-2 \times 0,5-1 \mathrm{~mm}$, pubescente; hipanto superior 1,5-2,5 × 3-3,5 mm, glabro; lobos do cálice inconspícuos ou pouco desenvolvidos ca. $1 \mathrm{~mm}$ compr., pilosos; estames com filetes do verticilo externo $2-2,5 \mathrm{~mm}$ compr., filetes do verticilo interno 1,5-2 $\mathrm{mm}$ compr.; anteras $0,5-0,7 \times$ 0,6-1 mm, cordiformes; disco nectarífero $0,5-1$ $\mathrm{mm}$ compr., viloso. Ovário $0,5-1 \times 0,2-0,5 \mathrm{~mm}$; estilete 2,5-3 mm compr.; estigma truncado. Fruto ca. 2,0 $\times 1 \mathrm{~cm}$, oval-elíptico, ápice apiculado, base curto-estipitada.

Material selecionado examinado: Guarapari, 15.V.1991, fl., V. de Souza 90 (CVRD, RB). Santa Teresa, 16.XII.1999, fr., V. Demuner 351 (MBML, RB).

Buchenavia tetraphylla é a espécie do gênero que apresenta a maior amplitude de distribuição geográfica, ocorrendo desde Cuba até o Brasil (Weaver 1991; Stace 2010). No Brasil, foi registrada para as regiões Centro-Oeste, Norte, Nordeste e Sudeste; tendo como limite de distribuição o sul do Espírito Santo (Stace 2010; BFG 2015). No Espírito Santo apresenta ampla distribuição e foi registrada em Floresta Ombrófila Densa e Vegetação com Influência Marinha e restinga (Garbin et al. 2017). Encontrada com flores no mês de maio e frutos em dezembro. 
2. Conocarpus L., Sp. Pl. 1: 176-177. 1753.

2.1. Conocarpus erectus L., Sp. Pl. 1: 176-177. 1753.

Figs. 1; 2i,j

Arbustos a árvores ca. $3 \mathrm{~m}$ alt. Folhas 1,7-2,9 × 0,5-1,2 cm, alternas, subcoriáceas; lâmina lanceolada ou oblanceolada, ápice agudo ou arredondado, base atenuada; nervação broquidódroma, 5-7 pares de nervuras secundárias; pecíolo 1-4 mm compr., com duas glândulas secretoras de sal. Inflorescências 6-7 × 4-5 mm, em capítulos globosos, terminais e/ou axilares. Bractéola 1, com 2,5-4,5 × 0,5-1 mm, lanceolada. Botão floral e flores não observados. Frutos 2-3 $\times 2,3-3,5 \mathrm{~mm}$, imbricados, reflexos, geralmente hipanto superior persistente, subséssil.

Material examinado: Aracruz, Estação de Biologia Marinha de Santa Cruz, 16.V.1989, fr., O.J. Pereira et al. 1970 (VIES). Guarapari, 24.VIII.1987, fr., O.J. Pereira et al. 989 (VIES). Vitória, manguezal da UFES, 15.III.1984, fr., T.M.S. Carmo s.n. (VIES 285).

Conocarpus erectus distingue-se das demais espécies de Terminaliinae pelas flores e frutos agrupados em capítulos globosos. Ocorre nas Américas desde o litoral meridional da Flórida, passando pelo México (América do Norte) a América do Sul, no litoral do Equador ao Brasil (Linsigen et al. 2009; Stace 2010), sempre associada à ambientes de manguezal. No Brasil, a espécie foi registrada nas regiões Norte, Nordeste, Sudeste e Sul (BFG 2015). No estado do Espírito Santo foram verificados poucos registros para a espécie, provavelmente devido à carência de coletas. Conocarpus erectus foi encontrada em regiões de manguezal no estado. Registrada com flores em maio e frutos entre março e agosto. Conhecida como "mangue de botão".

\section{Terminalia L. Syst. Nat. 12. (2): 674. 1767.}

Arbustos a árvores. Folhas reunidas no ápice dos ramos, geralmente elípticas, obovadaelípticas a obovadas; glândulas 2 ou ausentes. Domácias, em geral, ausentes. Inflorescências em racemos de espigas, terminais e/ou axilares. Flores hermafroditas. Hipanto inferior fusiforme, cilíndrico ou 5-anguloso; hipanto superior campanulado, lobos do cálice 5, conspícuos. Cálice 5-lobado, lobos desenvolvidos e agudos. Pétalas ausentes. Estames com filetes espessos e curtos; anteras versáteis. Disco nectarífero geralmente desenvolvido. Fruto betulídeo, arredondado ou complanado, seco ou carnoso, coriáceo ou membranácea, 2-5-alado.

Terminalia compreende 200 espécies ocorrentes na região tropical das América, África, Oceania e Ásia, sendo este último continente o que apresenta maior número de espécies e considerável diversidade morfológica (Stace 2010). Na região Neotropical, o gênero está representado por 34 espécies, destas 23 ocorrem no Brasil. Em território brasileiro, Terminalia é mais bem representada em vegetação de Mata atlântica com nove espécies, sendo quatro no Espírito Santo (BFG 2015).

\section{Chave de identificação das espécies de Terminalia ocorrentes no Espírito Santo}

1. Glândulas ausentes no pecíolo 3.2. Terminalia glabrescens

1’. Glândulas presentes no pecíolo.

2. Folhas seríceo-cinéreas, principalmente quando jovens; nervação eucamptódroma-broquidódroma a broquidódroma com 5-8 pares de nervuras secundárias 3.1. Terminalia argentea

2'. Folhas subglabras, estrigosas, seríceas ou rufo-seríceas; nervação eucamptódroma-broquidódroma a broquidódroma com 4-13 pares de nervuras secundárias.

3. Folhas coriáceas; nervação eucamptódroma-broquidódroma; fruto com alas oblongas e rígidas 3.3. Terminalia januarensis

3'. Folhas cartáceas a subcoriáceas; nervação broquidódroma; fruto com alas oblongo-elípticas e membranáceas 3.4. Terminalia mameluco

3.1. Terminalia argentea Mart. Nov. Gen. Sp. Pl. 1: 43.1824. Figs. 3; 4a-c

Árvore 7-50 m alt., glabra. Folhas 4,9-7 $\times$ 1,8-2,6 cm, coriáceas; lâmina elíptica a obovadaelíptica a obovada, ápice arredondado a acuminado, base atenuada, seríceo-cinérea, principalmente quando jovens e subglabras, quando maduras, em ambas as faces; nervação eucamptódromabroquidódroma a broquidódroma, 5-8 pares de nervuras secundárias; pecíolo $0,9-2 \mathrm{~cm}$ compr.; glândulas 2, no ápice do pecíolo; domácias ausentes. Inflorescência, bractéola, botões florais e 
flores não observados. Fruto 1,5-3,6 ×2,8-7,4 cm, 2-alado; alas 1,5-3,6 × 1,2-3,5 cm, arredondadas, rígidas, mais largas que o corpo do fruto; região central 2-2,2 × 1,1-1,3 cm.

Material selecionado examinado: Jaguaré, Barra Seca, 15.IV.1996, fr., G. Hupp 4 (MBML, RB). Linhares, Reserva Natural Vale, 4.IX.2012, fr., G.S. Siqueira 774 (CRVD, RB).

Terminalia argentea pode ser reconhecida por suas folhas seríceo-cinéreas, principalmente quando jovens, nervação eucamptódroma-broquidódroma a broquidódroma com 5-8 pares de nervuras secundárias e duas glândulas no pecíolo. Distribuise no Brasil, Bolívia e Paraguai (Stace 2010). No Brasil, a espécie ocorre em todas as regiões do país (BFG 2015). Para o Espírito Santo, foi registrada na Reserva Natural Vale em Linhares em Floresta Ombrófila Densa. Segundo CNCFlora (2017), Terminalia argentea é uma espécie considerada "pouco preocupante" (LC). Coletada com frutos entre abril e setembro. Popularmente conhecida por "capitão do campo".

\subsection{Terminalia glabrescens Mart. Flora $20(2$} Beibl.): 124. 1837.

Figs. 3; 4d-f

Árvores ca. $25 \mathrm{~m}$ alt., glabra. Folhas 10,8-12,6 × 5,7-6,4 cm, subcoriáceas; lâmina obovada, ápice retuso, base atenuada, rufo-serícea, em ambas as faces; nervação broquidódroma, 8 pares de nervuras secundárias; pecíolo 1,4-1,7 cm compr.; glândulas e domácias ausentes. Inflorescências 4,8-7,5 cm compr., racemos de espigas, densifloras, axilares ou terminais; espigas

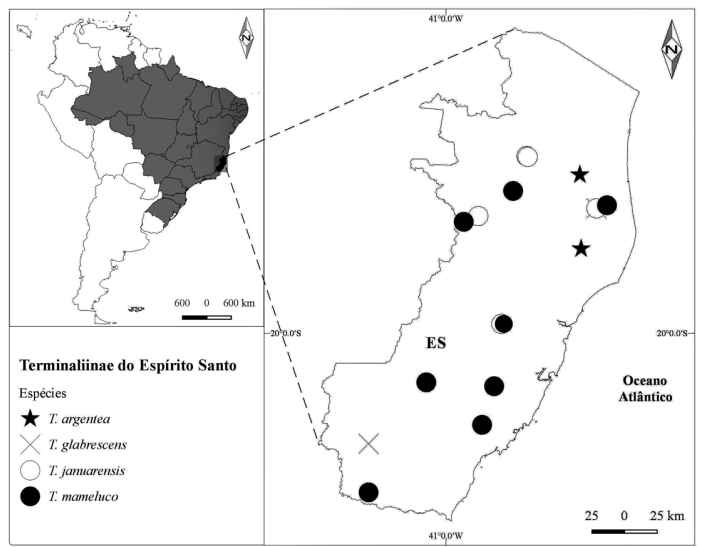

Figura 3 - Distribuição de Terminalia no estado do Espírito Santo, Sudeste do Brasil.

Figure 3 - Distribution of Terminalia in Espírito Santo state, Southeastern Brazil.
2,3-7,2 cm compr., pedúnculo 0,9-1,6 cm compr., raque $1,3-6 \mathrm{~cm}$ compr., bractéola ca. $1,6 \times 0,2 \mathrm{~mm}$, estreito-triangular, vilosa; botão floral $1,5-2,5$ $\times 1,2-1,5 \mathrm{~mm}$. Flores $2,5-3,5 \times 2,5-3,0 \mathrm{~mm}$, esverdeadas; hipanto inferior 1,1-1,2 ×0,5-1 mm, viloso-tomentoso; hipanto superior 1,6-1,7 × 2-2,2 $\mathrm{mm}$, viloso-tomentoso; lobos do cálice ca. 0,5 × 0,7 $\mathrm{mm}$, triangulares, viloso-tomentosos; estames com filetes do verticilo externo ca. $2 \mathrm{~mm}$ compr., filetes do verticilo interno ca. $2,5 \mathrm{~mm}$ compr., anteras. $0,3-0,5 \times 0,3 \mathrm{~mm}$, elípticas; disco nectarífero 1,5 $\mathrm{mm}$ diâm, aneliforme, viloso. Ovário $0,4-0,5 \times$ $0,3 \mathrm{~mm}$; estilete ca. $2,3 \mathrm{~mm}$ compr., filiforme; estigma ca. 0,2 mm diâm. Fruto 1,8-2,2 × 0,5-0,7 $\mathrm{cm}, 5$-alado, alas desiguais, 2 alas mais largas que o corpo do fruto e 3 menores, arredondandas, escariosas; região central ca. 1-1 × 1,1 cm.

Material examinado: Alegre, São João do Norte, 5.VIII.2008, bot e fl., V.C. Manhães 101 (MBML, VIES). Linhares, Reserva Florestal da Vale, 20.IX.1973, fl. e fr., J. Spada 312 (RB).

Terminalia glabrescens caracteriza-se pelas folhas subcoriáceas, obovadas, rufo-seríceas, nervação broquidódroma com 8 pares de nervuras secundárias e frutos 5-alados. Segundo Stace (2010), a espécie distribui-se no Brasil, Bolívia e Paraguai. Em território brasileiro, ocorre em todas as regiões do país (BFG 2015). No Espírito Santo foi registrada em Floresta Oombrófila Densa. Coletada com flores em agosto e setembro. Denominada popularmente como "pequi".

3.3. Terminalia januarensis DC. Prodr. 3: 11. 1828.

Figs. 3; 4g,h

Árvore a arbusto, 3-28 m alt., glabra. Folhas $3,1-16,8 \times 1,5-5,4 \mathrm{~cm}$, coriáceas; lâmina elíptica a obovada-elíptica, ápice agudo a acuminado, base cuneada, subglabra, estrigosa ou serícea; nervação eucamptódroma-broquidódroma, 5-13 pares de nervuras secundárias; pecíolo $0,5-2,6 \mathrm{~cm}$ compr.; glândulas 2 , no ápice do pecíolo; domácias ausentes. Inflorescência, bractéola, botões florais e flores não observadas. Fruto 1,3-3,8 × 3,2-9,8 cm, 2-alado; alas 1,2-3,6 × 1,4-4,8 cm, oblongas, rígidas, mais largas que o corpo do fruto; região central 1-3,7 × 0,5-1,1 cm.

Material examinado: Nova Venécia, trilha principal na Mata do Fuxico, 18.VII.2008, fr., R.C. Forzza 5203 (MBML, RB). Pancas, Distrito de Lajinha, 12.II.2014, fr., R.C. Forzza 7723 (RB). Santa Teresa, Bairro Alvorada, 10.III.2005, fr., T.A. Cruz (MBML 25079).

Terminaliajanuarensis pode ser reconhecida $\mathrm{e}$ diferenciada de T. mameluco, espécie mais próxima, por possuir folhas maiores $(3,1-16,8 \times 1,5-5,4 \mathrm{~cm})$ 


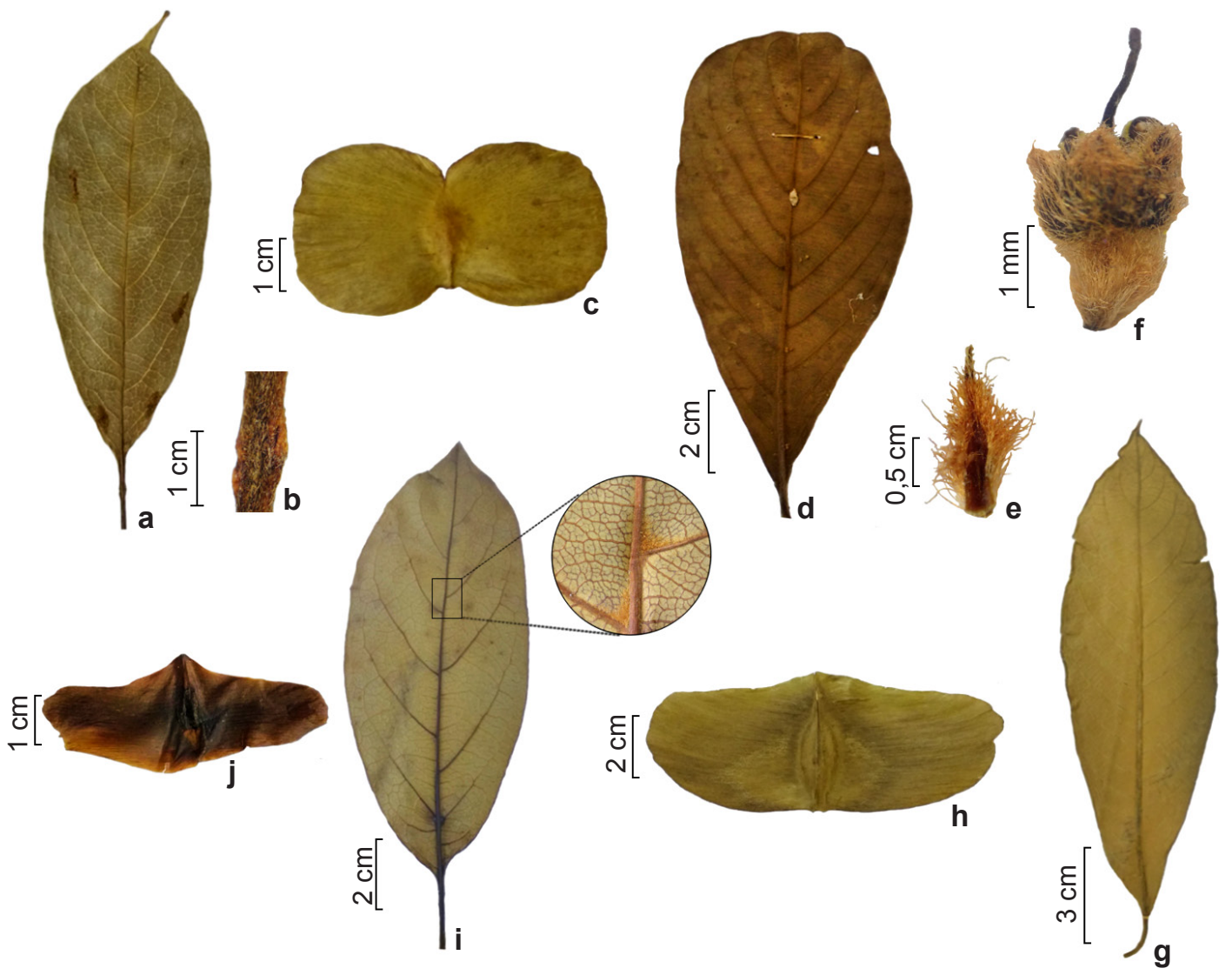

Figura 4 - a-c. Terminalia argentea - a. folha, b. glândulas peciolares, c. fruto. d-f. T. glabrescens - d. folha, e. bracteóla, f. flor. g-h. T. januarensis - g. folha, h. fruto. i-j. T. mameluco - i. folha e detalhe das domácias na axila da nervura principal com as nervuras secundárias, j. fruto. (a-c. G.S. Siqueira 774, RB 644330; d-f. V.C. Manhães 101, MBML 40094; g,h. T.A. Cruz, MBML 25079; i,j. G. Hatschbach 71472, BHCB 39240).

Figure 4 - a-c. Terminalia argentea - a. leaf, b. petiolar glands, c. fruit. d-f. T. glabrescens - d. leaf, e. bracteole, f. flower. g-h. T. januarensis - g. leaf, h. fruit. i-j. T. mameluco - i. leaf and detail of domatia in the axilla of the main vein with the secondaries veins, j. fruit. (a-c. G.S. Siqueira 774, RB 644330; d-f. V.C. Manhães 101, MBML 40094; g,h. T.A. Cruz, MBML 25079; i,j. G. Hatschbach 71472, BHCB 39240).

e coriáceas ( $v s$. cartáceas a subcoriáceas), nervação eucamptódroma-broquidódroma com 5-13 pares de nervuras secundárias ( $v s$. nervação broquidódroma com 4-6 pares de nervuras secundárias), fruto com alas oblongas e rígidas ( $v s$. alas oblongo-elípticas e membranáceas). A similaridade entre as duas espécies também foi reportada por Stace (2010). Terminalia januarensis é endêmica do Brasil, restrita as regiões Nordeste e Sudeste do país (Stace 2010; BFG 2015). No estado do Espírito Santo foi encontrada em Floresta Ombrófila Densa. Registrada na Reserva Natural Vale e Área de Proteção Ambiental da Pedra do Elefante. A espécie é considerada rara ou vulnerável, representada por árvores de grande porte, encontrada em mata úmida (floresta ombrófila densa) (Marquete 2003; Stace 2010). Coletada com frutos de setembro a março. Popularmente denominada "capitão do campo".

\subsection{Terminalia mameluco Pickel, Arq. Bot. Estado} São Paulo 3: 200. 1958.

Figs. 3; 4i,j

= Terminalia kuhlmannii Alwan \& Stace, Ann. Missouri Bot. Gard. 76(4): 1126. 1989.

Árvore 5-30 m alt., glabra. Folhas 2,3-12,9 $\times 2-5,3 \mathrm{~cm}$, cartáceas a subcoriáceas; lâmina elíptica a obovada, ápice agudo a acuminado, base atenuada; subglabra ou serícea apenas ao longo da nervura principal; nervação broquidódroma, 4-6 pares de nervuras secundárias; pecíolo 1-1,5 cm compr.; glândulas 2, no ápice do pecíolo; 
domácias presentes ou ausentes. Inflorescência, bractéola, botões florais e flores não observadas. Fruto 1,4-3,5 × 1,6-5,6 cm, 2-alado; alas 1,4-1,6 $\times$ 1,4-2,2 cm, oblongo-elípticas, membranáceas, mais largas que o corpo do fruto; região central $1,4-1,6 \times 0,3-0,4 \mathrm{~mm}$.

Material examinado: Alfredo Chaves, 18.X.2000, veg., G. Hatschbach 71421 (HUFU, RB). Domingos Martins, 19.III.1991, fr., V. de Souza 42 (RB). Goitacazes, Rio Doce, 16.XII.1943, fr., J.G. Kuhlmann 6688 (RB). Linhares, 1.XII.2006, fr., E.J. Lucas 921 (EAC, ESA, MBML, RB). Nova Venécia, APA Pedra do Elefante, 28.III.2009, fr., A.M. Assis 2364 (MBML). Pancas, Pedra da Colina, 11.III.2016, fr., L.O. Azevedo 412 (RB). Santa Teresa, Parque Natural Municipal de São Lourenço, 11.VIII.2003, veg., T.A. Cruz 84 (RB). São Gabriel da Palha, 28.I.1998, fr., Lorenzi 1932 (RB). Venda Nova do Imigrante, 20.X.2000, fr., G. Hatschbach 71472 (BHCB, MBML, RB, UB).

Terminalia mameluco pode ser reconhecida devido as folhas cartáceas a subcoriáceas, nervação broquidódroma com 4-6 pares de nervuras secundárias, fruto com alas oblongo-elípticas e membranáceas. Terminalia mameluco é endêmica do leste do Brasil e ocorre nas regiões Nordeste e Sudeste do país (BFG 2015). No Espírito Santo foi encontrada em Floresta Ombrófila Densa. Registrada na APA Pedra do Elefante, Parque Natural Municipal de São Lourenço e Reserva da Companhia Vale do Rio Doce. Conhecida popularmente como "capitão do campo" ou "pelada".

\section{Agradecimentos}

À CAPES (Coordenação de Aperfeiçoamento de Pessoal de Nível Superior), a bolsa de doutorado concedida à primeira autora. Ao $\mathrm{CNPq}$ (Conselho Nacional de Desenvolvimento Científico e Tecnológico), as bolsas de produtividade concedidas a Margareth Ferreira de Sales e Maria Iracema Bezerra Loiola. A toda equipe do Laboratório de Sistemática e Ecologia Vegetal (LASEV-UFC), o apoio nas diversas etapas de elaboração deste trabalho (http://www.lasevufc.com/). Aos curadores dos herbários mencionados no texto, em especial BHCB, MBML, RB e VIES, a doação, empréstimo e permissão para visita aos acervos.

\section{Referências}

Alwan ARA (1983) The taxonomy of Terminalia (Combretaceae) and related genera. Tese de Doutorado. Universidade de Leicester, Leicester. 353p.

BFG - The Brazil Flora Group (2015) Growing knowledge: an overview of seed plant diversity in Brazil. Rodriguésia 66: 1085-1113.
Cavalcanti Filho JR, Silva TF, Nobre WQ, Souza LIO, Silva FCS, Figueiredo RC, Gusmão NB, Silva MV, Nascimento LC \& Correia MT (2017) Antimicrobial activity of Buchenavia tetraphylla against Candida albicans strains isolated from vaginal secretions. Pharmaceutical Biology 55: 1521-1527.

CNCFlora (2017) Combretaceae. In: Lista vermelha a flora brasileira. Versão 2012.2. Centro Nacional de Conservação da Flora. Disponível em <http:// cncflora.jbrj.gov.br/portal/pt-br>. Acesso em 15 maio 2017.

Cock IE (2015) The medicinal properties and phytochemistry of plant of the genus Terminalia (Combretaceae). Progress in Drug Research 23: 203-229.

CRIA - Centro de Referência em Informação Ambiental (2017) Geoloc. Disponível em < http://splink.cria. org.br/>. Acesso em 23 março 2017.

Eichler AG (1867) Combretaceae. In: Martius CFP, Eichler AW \& Urban I (eds.) Flora brasiliensis. Monachii et Lipsiae, Munchen, Wien, Leipzig. Vol. 14, Pp. 77-128.

Engler HGA \& Diels L (1900) Combretaceae Combretum. In: Engler HGA (org.) Monographien afrikanischer PflanzenFamilien und Gattungen. Vol. 3. Engelmann, Leipzig. Pp. 1-116.

Exell AW \& Stace CA (1966) Revision of the Combretaceae. Boletim Sociedade Broteriana 40: 5-25.

Garbin, ML, Saiter, FZ, Carrijo TT \& Peixoto AL (2017) Breve histórico e classificação da vegetação capixaba. Rodriguésia 68: 1883-1894.

Gere J (2013) Combretaceae: phylogeny, biogeography and DNA barcoding. 2013. 195 f. Tese de Doutorado. Universidade de Johannesburg, Johannesburg. 195p.

Hickey LJ (1973) Classification of the architecture of dicotyledonous leaves. American Journal of Botany 60: 17-33.

IPNI - The International Plant Names Index (2017) The International Plant Names Index. Disponível em $<$ http://www.ipni.org > . Acesso em 2 abril 2017.

Linsigen LV, Cervi AC \& Guimarães O (2009) Sinopse taxonômica da família Combretaceae R. Brown na Região Sul do Brasil. Acta Botanica Brasílica 23: 738-750.

Loiola MIB, Rocha EA, Baracho GS \& Agra MF (2009) Flora da Paraíba: Combretaceae. Acta Botanica Brasílica 23: 330-342.

Marquete NFS (1984) Combretaceae do estado do Rio de Janeiro. Subtribo Terminaliineae. Rodriguésia 36: 91-104.

Marquete NFS \& Valente MC (1992) Buchenavia pabstii Marq. et Val., uma nova espécie de Buchenavia para o Espírito Santo (Brasil). Atas da Sociedade Botânica do Brasil 3: 113-116. 
Marquete NFS \& Valente MC (1997) Combretaceae. In: Marques MCM \& Martins HF (orgs.) Flora do estado do Rio de Janeiro. Albertoa 4: 13-51.

Marquete NFS, Teixeira J \& Valente MC (2003) Terminalia L. (Combretaceae) na Região Sudeste do Brasil. Bradea 16: 99-123.

Marquete NFS (2012) Combretaceae. In: Lista de espécies da flora do Brasil. Jardim Botânico do Rio de Janeiro. Disponível em <http:// floradobrasil.jbrj.gov.br/2012/ FB000090> Acesso em 20 abril 2017.

Maurin O, Chase MK, Jordaan M \& Vanderbank M (2010) Phylogenetic relationships of Combretaceae inferred from nuclear and plastid DNA sequence data: implications for generic classification. Botanical Journal of the Linnean Society 162: 453-476.

Pádua PF, Dihl RR, Lehmann M, Abreu BR, Richter MF \& Andrade HH (2013) Genotoxic, antigenotoxic and phytochemical assessment of Terminalia actinophylla ethanolic extract. Food and Chemical Toxicology 62: 521-527.

Quantum GIS Development Team (2017) Quantum GIS Geographic Information System. Open Source Geospatial Foundation Project. Disponível em $<$ http://qgis.osgeo.org/>. Acesso em 15 abril 2017.

Radford AE, Dickson WC, Massey JR \& Bell CR (1974) Vascular plant systematics. Harper \& Row, New York. 891p.
Ribeiro SS, Jesus AM \& Anjos CS (2012) Evaluation of the cytotoxic activity of some Brazilian medicinal plants. Planta Medica 78: 1601-1606.

Soares Neto RL, Cordeiro LS \& Loiola MIB (2014)Flora do Ceará, Brasil: Combretaceae. Rodriguésia 65: 685-700.

Sousa VF, Ribeiro RTM, Loiola MIB \& Versieux LM (no prelo) Combretaceae no estado do Rio Grande do Norte, Brasil. Rodriguésia.

Stace CA (1965) The significance of the leaf epidermis in the taxonomy of the Combretaceae. 1. A general review of tribal, generic and specific characters. The Journal of the Linnean Society Botany 59: 229-252.

Stace CA (2010) Combretaceae. Flora Neotropica 107. The New York Botanical Garden Press, New York. 369p.

Thiers B [continuously updated] Index Herbariorum: a global directory of public herbaria and associated staff. New York Botanical Garden's Virtual Herbarium. Disponível em $<$ http:// sweetgum.nybg.org/ih/>. Acesso em 28 abril 2017.

Weaver PL (1991) Buchenavia capitata (Vahl.) Eichler: Granadillo. Department of Agriculture, Forest Service, Southern Forest Experiment Station, New Orleans. 7p.

Lista de exsicatas examinadas

A Assis MBML (47658) (3.4). AM Assis 2364 (3.4). DA Folli 258 (3.2), 288 (3.4), 384 (1.1), 496 (3.4), 544 (1.3), 777 (1.4). ACS Dal \& J Rodrigues Filho 55 (2.1). EJ Lucas 921 (3.4). G Hatschbach 71421 (3.4), 71472 (3.4). G Hupp 4 (3.1). GE Valente et al. 13109 (2.1). GQ Freira 135 (3.4). GS Siqueira 774 (3.1). IA Silva 226 (1.1), 356 (3.4). J Spada 312 (3.2). JG Kuhlmann RB (25743) (1.2), 6688 (3.4). JPF Zorzanelli \& AE Silva 470 (3.2). L Krieger CESJ (19581) (2.1). LO Azevedo 412 (3.4). Lorenzi 1932 (3.4). MLL Martins 35 (2.1). O Yano SP (232428) (2.1). OJ Pereira et al. 989 (2.1), 1970 (2.1). PC Vinha 1391 (2.1); P.R. Souza VIES (1530) (2.1). RA Curto et al. 182 (3.2). RC Forzza 5203 (3.3), 7723 (3.3). TA Cruz MBML (25079) (3.3), 84 (3.4). TMS Carmo VIES (285) (2.1). TS dos Santos 951 (1.2). V de Souza 42 (3.5), 90 (1.4). V Demuner 351 (1.4). VC Manhães 101 (3.2). VD Souza 217 (2.1). 
